\title{
Learning environments preferred by university students: a shift toward informal and flexible learning environments
}

\author{
Teemu Valtonen $^{1}$ (D) . Ulla Leppänen ${ }^{1} \cdot$ Mareena Hyypiä $^{1} \cdot$ Anna Kokko ${ }^{1}$. \\ Jyri Manninen $^{1} \cdot$ Henriikka Vartiainen $^{1} \cdot$ Erkko Sointu $^{1} \cdot$ Laura Hirsto $^{1}$
}

Received: 25 November 2019 / Accepted: 30 September 2020 / Published online: 22 November 2020

(c) The Author(s) 2020, corrected publication 2021

\begin{abstract}
Universities are facing new challenges that pose various demands for developing learning environments. These challenges are related to different pedagogical approaches, the use of information and communications technology (ICT), the diversification of student populations, and new expectations related to working life. This study focused on university students' perceptions of preferred learning environments and their thoughts about the best learning environments for the higher-education level. The main data consisted of answers to open questions from 230 students. Additionally, a questionnaire was used to gain an overall picture of students' experiences in the current learning environment. Five main themes emerged: characteristics of the campus; available resources; flexibility of learning opportunities; pedagogy; and implementation of ICT in education. Further, two larger perspectives were highlighted. One was the need for informal learning environments (where students can study alone or with peers or just hang out). The second perspective pertains to the flexibility of learning, demonstrating the need for learning environments that allow participation without the need to come to the campus for face-to-face meetings. The need for resources (particularly ICT and the support and availability of teaching personnel) was also highlighted. The study provides important perspectives for developing appropriate learning environments for higher education.
\end{abstract}

Keywords Higher education · ICT in education · Learning environment · Learning space

\section{Introduction}

Universities are facing new challenges that put increasing pressure on the development of learning environments (McCune and Entwistle 2011). Many of these challenges are related to the application of new pedagogical approaches, the rapid development of educational technology, the diversification of non-traditional student populations in need of flexible courses, and the growing expectations related to the skills needed in current and future working life. These changes also align with a bigger transformation described by Barr and Tagg (1995) as the shift

Teemu Valtonen

Teemu.valtonen@uef.fi

1 Faculty of Philosophy, University of Eastern Finland, Kuopio, Finland 
from an instruction paradigm to a learning paradigm, or from broadcasting knowledge to students to knowledge construction (Harasim 1996). In other words, there has been a shift toward more student-centered teaching and learning practices. Even though these references are relatively old, they are still valid if viewed in relation to current development aims. Based on the annual Horizon reports for higher education (Becker et al. 2018), physical environments demand modification so that they can better meet the needs of today's pedagogical practices which highlight the active role of students. Traditional university lecture halls allow modifying learning settings to meet the needs of neither contempoary pedagogical practices nor the effective use of modern learning technologies.

In addition, there are new expectations related to the learning goals. Along with the traditional content learned, students are expected to gain the so-called twenty-first century skills (Voogt and Pareja Roblin 2012) or skills for present and future work environments. Some examples of the twenty-first century skills include creative and critical thinking, collaboration and communication skills, social and/or cultural competencies, ICT literacy, and problem-solving skills. According to Häkkinen et al. (2017), educational institutions must incorporate these skills and the teaching practices supporting them into their curricula. Again, these teaching practices pose demands for better learning environments that accommodate students' active participation with ICT devices and learning as a team of experts. For these activities, broadcasting information to students within auditoriums is not a good option.

Another significant change in higher education involves the use of information and communications technology (ICT). The development of ICT and related pedagogical practices is occurring rapidly. ICT is a central element of twenty-first-century skills and a major means of supporting modern teaching and learning practices. According to Ossiannilsson (2018), ICT plays an important role in making higher education more flexible and broadly accessible. The 2018 Horizon report indicated several developing trends within ICT in higher education, including learning analytics, adaptive technologies, and mobile learning (Becker et al. 2018). Higher education approaches incorporating ICT (e.g., blended learning, massive open online courses [MOOC], and flipped classroom strategies with online video materials) provide new ways to develop higher-education learning practices and make higher education more flexible.

The development of university learning environments is key to meeting expectations for higher education and enabling the use of different pedagogical approaches with modern technology. According to Fisher and Newton (2014) and Jessop et al. (2012), students' perspectives need to be considered when developing learning environments. Students' perspectives are also considered important for quality assurance and research-based quality enhancement in higher education (Hirsto 2013). The aim of the current study was to identify the learning environments preferred by students by understanding the best learning environment for the higher-education level from their perspective. The themes described within this article are well known based on the recent literature. The overarching goal of this study was to provide insights into students' perspectives about the learning environments that best serve them in their higher-education studies.

\section{Theoretical background: learning environments}

There are several definitions of learning environments. Manninen et al. (2007) define such environments using five different perspectives, which can be used to contemplate the different elements of the environment: physical spaces, teaching and learning approaches, social and collaborative aspects supporting learning, technologies used, and contextual learning places 
outside the campus (e.g., work placements and field visits in biology). Radcliffe (2008) defines a learning environment by using the Pedagogy-Space-Technology framework for designing and evaluating such environments. This framework highlights connections among different elements of a learning environment, which are useful when considering learning environments that are used either for individuals (individual rooms) or for networks (whole campus) (Radcliffe 2008). According to Beckers et al. (2015), informal learning environments are important when supporting individual and small groups for the benefit of social or individual study activities in both the real and virtual worlds. This indicates the importance of providing learning environments outside seminar rooms and auditoriums. As Jamieson (2009) indicates, all campus areas should be seen as campus learning centers.

In the following sections, the characteristics of learning environments are discussed in accordance with the definitions provided by Radcliffe (2008) and Manninen et al. (2007). Learning environments are divided into three larger areas (physical space, ICT, pedagogy), thus covering the descriptions of learning environments provided above. According to Radcliffe (2008), pedagogy is enlarged by technology and enabled by space, space encourages pedagogy and embeds the technology, and technology enhances pedagogy and extends the space.

\section{Physical space}

Recently, the importance of physical spaces (e.g., buildings, seminar and lecture rooms) has gained widespread acknowledgement in educational research settings (Vercellotti 2018). Changes in teaching and learning practices challenge traditional learning spaces (e.g., lecture halls), which support the broadcasting model (Harasim 1996) and are unsuitable for shared knowledge building or collaborative work by students. Carr and Fraser (2014) outline development trends pertaining to physical spaces. These spaces enable the use of different pedagogical approaches with ICT, the application of collaborative and active learning practices, and the use of students' own ICT devices, while also being comfortable and containing spaces for informal and increasingly-integrated online learning. According to Van Note Chism (2002), today's learning spaces must be able to accommodate small-group meetings, project work, and dialogues. Moreover, learning spaces need to have easily-accessible technologies and tools for displaying and working with documents. Van Note Chism (2002) also highlights the importance of these spaces' comfort, lighting, and acoustics. According to Morieson et al. (2018), there must be convenient, comfortable, and quiet places where students can focus on studying. Beckers et al. (2016) found that the use of learning space depends on learning tasks; for self-study, students prefer to study at home while, for more collaborative work, they choose the university campus.

The design of a learning space does not ensure that it will be used a particular way or according to particular pedagogical practices (Carr and Fraser 2014). Nevertheless, according to Whiteside, Brooks, and Walker (2010), the flexibility of a physical space can affect teachers' ways of teaching; when in a more flexible space, teachers emphasize the use of more student-centered practices. Additional factors that have positive effects on well-being and learning at schools include: vegetation, soft furnishings, and lower seating density (Scannell et al. 2016); indoor and outdoor cleanliness and campus security (Kärnä et al. 2013); good-quality indoor air and temperature (Chatzidiakou et al. 2012; Yang et al. 2013); acoustics (Van Note Chism 2002); and natural elements, such as outside views and plants (Beckers et al. 2016). 


\section{Information and communications technology in higher education}

In recent decades, several different approaches have been employed for using ICT to support teaching and learning in higher education. The development of ICT has been rapid, with Horizon Reports concerning higher education outlining present and future applications of ICT in higher education (Becker et al. 2018). Trends are often built on specific technologies, such as tablets, mobile phones, wearable technology, and 3D printing. Other trends according to recent Horizon Reports are based more on pedagogical approaches, such as flipped classrooms, makerspaces, and games and gamification (Becker et al. 2018; Johnson et al. 2014). The latest Horizon Report (Alexander et al. 2019) identified today's trends as mobile learning and analytic technologies. In the near future, mixed reality and artificial intelligence (AI) are expected to play more-important roles in education and, in the next four to five years, development trends are anticipated to focus on blockchain and virtual assistants for supporting learning. From the Horizon Reports, one can see the potentially vast area covered by ICT in higher education and encompassing various technological and pedagogical approaches.

An important aspect of today's university-level teaching is the use of students' personal devices. The bring-your-own-device (BYOD) approach has several benefits, such as reducing the need for the university to purchase devices for different spaces. Furthermore, the devices are already familiar to the students and their maintenance is the student's responsibility. In order to maximize the potential of BYOD, the infrastructure must be modified as well, meaning that a wireless local area network (WLAN) and places for charging devices (Cheng et al. 2016) should be available to students.

Different online environments are poised to play similarly important roles. Some of the concepts related to these environments include learning management systems (LMS), course management systems (CMS), virtual learning environments (VLE), and knowledge management systems (KMS), which can all be seen as more or less synonymous (Moore et al. 2011). Typically, these concepts refer to online environments (e.g., Moodle) that contain tools for delivering learning materials, creating areas for collaboration, designing different tasks and assignments, assessing students' work, and collecting and managing user data. Additionally, different cloud computing services are gaining increasing attention as highereducation learning environments (Al-Samarraie and Saeed 2018; González-Martínez et al. 2015). Within this paper, we make the distinction between an LMS such as Moodle and cloud computing services, such as G Suite for Education by Google or Office 365 by Microsoft, based on the role of the student. In addition to their LMS applications, cloud computing services can also be considered as personal learning environments (PLEs), meaning that students are able to build, administer, and modify the environments for their personal aims and use the applications that they choose (Valtonen et al. 2012). In comparison, the teacher builds and administers the learning environment in typical LMS-like Moodle, with students only completing the pre-defined path designed by the teacher.

\section{Pedagogy in higher education}

During the last few decades, there has been a shift pedagogical practices from knowledge transmission to knowledge construction (Harasim 1996). The transmission model is wellsuited for higher education conducted in large lecture halls where content can be distributed to large numbers of students simultaneously. More-recent views interpret teaching and 
learning as the process of knowledge building with more-active student participation and more collaborative activities (Harasim 1996). Overall, the role of pedagogy in higher education has been increasingly emphasized in recent years. According to Harris and Cullen (2008), professional preparation in higher education, even for teaching assignments, was previously strongly discipline-based. Now, the role of pedagogy is gaining more attention.

Several approaches and models have been introduced for developing more studentcentered ways of teaching and learning. For instance, blended learning involves a cohesive learning experience for students by mixing both online and face-to-face formats and allowing students flexible use of time and space (Olakanmi 2017). One example of blended learning is the flipped classroom (FC) approach wherein lectures are replaced with video clips and other materials for students to study before the face-to-face meeting (Sointu et al. 2019). The aims of FC are to provide students with the ability to better focus on challenging topics with their peers and teachers and to develop student-centered teaching and learning practices focused on collaborative knowledge building. Additionally, the problembased learning (PBL) model has been actively developed and used in higher education. This model is based on learning topics that are organized around shared, open-ended problems relevant to students' everyday life (Jonassen and Hung 2008). Collaborative learning is an essential element of the PBL model (Hung et al. 2008). In this model, students share their expertise, make collective decisions, and discuss their interpretations of issues (Hennessy and Murphy 1999). These approaches align with today's educational goals (Harasim 1996), such as the acquisition of the necessary twenty-first-century skills (Voogt and Pareja Roblin 2012), and provide strong content expertise along with more general abilities, such as learning, problem solving, and collaboration skills.

\section{Research objectives}

According to Casanova et al. (2018), students and teachers have traditionally played too small a role when designing learning environments for higher education. Similarly, the literature suggests that learning environments should be perceived and evaluated from the perspective of students (Yang et al. 2013) and that there is a need for more students' perspectives on learning environments (Fisher and Newton 2014; Jessop et al. 2012). The current paper fills this research gap by focusing on students' perceptions of higher- education learning environments, including the learning environments in which they currently study and what kinds of learning environments they prefer.

The research questions to address these objectives were as follows:

1. How do students assess their learning environments from the perspectives of physical learning spaces, ICT in education, and pedagogy?

2. What kinds of learning environments do students prefer and what is the best learning environment for higher education from their perspective?

In this study, we used a mixed-method approach: first, we analyzed students' responses to quantitative items concerning dimensions of their learning environments; and, second, we analyzed qualitative data based on open answers from 230 university students describing what they thought was a good university learning environment. 


\section{Methods}

The research data were collected during autumn 2015 from three campuses of a large multidisciplinary research university in Finland. This target university places strong emphasis on developing teaching and learning practices. This development focuses on pedagogical practices used, more student-centered approaches, and the development of learning environments. Learning environments vary from traditional lecture halls to more- flexible classrooms and laboratories equipped with the latest ICT facilities. The aim of the survey was to reach students who already had experience in studying at the university. As a result, third-year students were chosen as the target group. A total of 730 students (65.4\% women) from four faculties responded to a questionnaire containing structured and open questions. Currently, there are about 15,000 full-time students within the university (the yearly intake is approximately 3000). As the target group of this study consisted of the third-year students, 730 respondents is a good sample size (24.3\%, missing 2270), especially when considering the possibility that students drop out during their first few years. The average age of the respondents was 26.6 years $(\mathrm{SD}=8.0)$, with an age range of 19-64 years. The materials were mainly collected during contact periods of different courses, such as lectures. Through the teachers of different courses, students were also provided with information about the survey by e-mail and through the school's electronic bulletin boards. The questionnaire was available both in electronic and paper formats, because different departments preferred different strategies for organizing the survey. Participation was voluntary and respondents were well-informed about the survey, how the data would be analyzed, its objectives, and how results were to be distributed. All the respondents were adults.

As mentioned previously, this study followed a mixed-method approach (Creswell 2003). In order to provide a general picture of students' perceptions of the current learning environment, quantitative data were collected. Such data focused on three perspectives: physical learning environments, ICT used, and pedagogical practices (statements in Results section). This section contained data from all 730 students (missing data were excluded). The instrument was designed for this study based on the learning environment definitions provided by Radcliffe (2008) and Manninen et al. (2007). The instrument was developed in order to gain a general overview of the students' perceptions concerning their current learning environments. The quantitative data were analyzed by using only descriptive statistics (mean values and standard deviations), in order to provide a descriptive background for the section conducted using qualitative methods.

Meanwhile, the qualitative data contained answers to open questions from 230 students. These data consisted of students' perceptions of what constituted a good learning environment. Students were asked general questions, and specific aspects of learning environments were not mentioned to them. Responding students were able to pinpoint areas and perspectives related to learning environments according to what they perceived as important. The question was as follows: "The aim is to outline the best higher education-level learning environment. What would this learning environment be like and how could it be achieved?" The analysis of the qualitative data, including the development of the codebook, was conducted in phases by the three authors of this paper. During the first phase of the analysis, students' open answers were read through by the researchers with the aim of gaining an overview of the topics brought up by respondents. After this, the answers were coded by two researchers working together using ATLAS.ti version 8. One unit of analysis ranged from short mentions of the characteristics of the learning environment to longer mentions running to a maximum of two sentences. This phase was conducted using 
content-based analysis (Gibbs 2007) without using the codebooks from any previous studies. The aim of employing this approach was to highlight students' perceptions without pre-defined theoretical frames. This phase resulted in 95 codes that needed to be further categorized. After this, the codes were discussed by all three researchers and were further combined into five larger categories by the third researcher. The larger categories of Campus, Online, Pedagogy, Resources, and ICT in education were based on commonalities of codes and covered different characteristics of the learning environments. These categorizations have similarities with the descriptions of learning environments defined by Manninen et al. (2007) and Radcliffe (2008), again with unique characteristics based on this dataset. In order to provide more detailed insights into the five categories, the characteristics of the categories were further opened with nine more detailed sub-categories.

\section{Results}

We first report descriptive statistics for the quantitative data to portray students' experiences of physical learning spaces, ICT resources, and pedagogical practices. We then outline the five main categories identified in students' open answers. Lastly, the frequency of mentions of each category and sub-category is discussed.

\section{Assessment of current learning environments}

In terms of physical learning environments (Table 1), a need for more spaces for selfstudy both alone $(\mathrm{M}=3.12, \mathrm{SD}=1.33)$ and in groups $(\mathrm{M}=3.04, \mathrm{SD}=1.29)$ was identified. Students considered that the physical spaces they experienced were suitable for learning $(\mathrm{M}=3.98, \mathrm{SD}=1.15)$ and cozy $(\mathrm{M}=3.88, \mathrm{SD}=1.20)$, although means for these factors were below 4, suggesting that improvements are still needed.

Regarding ICT in learning (Table 2), students indicated that the ICT provided by the university was suitable for learning $(\mathrm{M}=3.98, \mathrm{SD}=1.16)$ and that the resources were sufficient $(\mathrm{M}=3.81, \mathrm{SD}=1.22)$, although again there was some room for improvement. Means were lower for the flexibility of ICT $(\mathrm{M}=3.42, \mathrm{SD}=1.11)$, especially use of personal ICT devices $(\mathrm{M}=3.29, \mathrm{SD}=1.50)$.

From a pedagogical perspective (Table 3), item means were at around the mid-point. Teachers' use of different pedagogical approaches was ranked the lowest $(M=3.36$, $\mathrm{SD}=1.13$ ). In comparison, their readiness to organize learning situations that supported student learning had a slightly better rating $(\mathrm{M}=3.78, \mathrm{SD}=1.09)$. Teachers' ability to use

Table 1 Physical learning spaces

\begin{tabular}{|c|c|c|c|c|}
\hline \multirow[t]{2}{*}{ Item wording } & \multicolumn{2}{|l|}{$n$} & \multirow[t]{2}{*}{ Mean } & \multirow[t]{2}{*}{ SD } \\
\hline & Valid & Missing & & \\
\hline The learning spaces of the university are cozy & 729 & 8 & 3.88 & 1.20 \\
\hline The learning spaces are very suitable for studying & 726 & 11 & 3.89 & 1.15 \\
\hline The University provides enough spaces for self-study & 710 & 27 & 3.12 & 1.33 \\
\hline $\begin{array}{l}\text { The University provides enough spaces for students to } \\
\text { study in groups }\end{array}$ & 680 & 57 & 3.04 & 1.29 \\
\hline
\end{tabular}


Table 2 ICT in learning

\begin{tabular}{|c|c|c|c|c|}
\hline \multirow[t]{2}{*}{ Item wording } & \multicolumn{2}{|l|}{$n$} & \multirow[t]{2}{*}{ Mean } & \multirow[t]{2}{*}{ SD } \\
\hline & Valid & Missing & & \\
\hline The ICT resources provided by the university are well-suited for learning & 718 & 19 & 3.98 & 1.16 \\
\hline $\begin{array}{l}\text { It is easy to use one's own ICT devices on the WLAN provided by the } \\
\text { university }\end{array}$ & 617 & 120 & 3.29 & 1.50 \\
\hline $\begin{array}{l}\text { The University's ICT resources work flexibly in different learning situa- } \\
\text { tions }\end{array}$ & 663 & 74 & 3.42 & 1.11 \\
\hline The University provides sufficient ICT resources for learning & 704 & 33 & 3.81 & 1.22 \\
\hline
\end{tabular}

Table 3 Pedagogical practices

\begin{tabular}{|c|c|c|c|c|}
\hline \multirow[t]{2}{*}{ Item wording } & \multicolumn{2}{|l|}{$n$} & \multirow[t]{2}{*}{ Mean } & \multirow[t]{2}{*}{ SD } \\
\hline & Valid & Missing & & \\
\hline $\begin{array}{l}\text { The teachers use various pedagogical methods in order to make learning } \\
\text { different contents easy for me }\end{array}$ & 726 & 11 & 3.36 & 1.12 \\
\hline $\begin{array}{l}\text { The pedagogical methods used by the teachers maintain my interest in the } \\
\text { studied content }\end{array}$ & 730 & 7 & 3.61 & 1.10 \\
\hline $\begin{array}{l}\text { The teachers are skilled at organizing learning situations that support my } \\
\text { learning }\end{array}$ & 706 & 31 & 3.78 & 1.09 \\
\hline
\end{tabular}

different methods in order to keep students interested in the content was rated at a similar level as their support of student learning $(\mathrm{M}=3.61, \mathrm{SD}=1.10)$.

\section{Qualitative analysis: characteristics of preferred learning environments}

The qualitative results indicated that the students' perceptions can be grouped into five main categories related to the desired elements of the learning environment: campus, online, pedagogy, resources, and ICT in education. This categorization aligns with the learning environment descriptions of Manninen et al. (2007) and Radcliffe (2008), although more-detailed perspectives for the aspects preferred by students are provided in the current work. Specifically, the elements of the Pedagogy-Space-Technology description presented by Radcliffe (2008) were updated to better reflect students' needs related to learning environments. These categories are described along with their sub-categories (see Fig. 1) and then the frequency of mentions of all categories is discussed.

The first main category, campus, was most-frequently mentioned, with 139 references by 91 respondents. This category contained the three sub-categories of environments, features, and services, with environments being the most mentioned. Responses in this category indicated the need for places where students can study in small groups with their peers, in pairs, or alone. Additionally, this category suggested a need for places to rest and just hang out and spend time with peers. These statements referred not to classrooms or lecture halls but to informal places for study or spending time within campus buildings: 


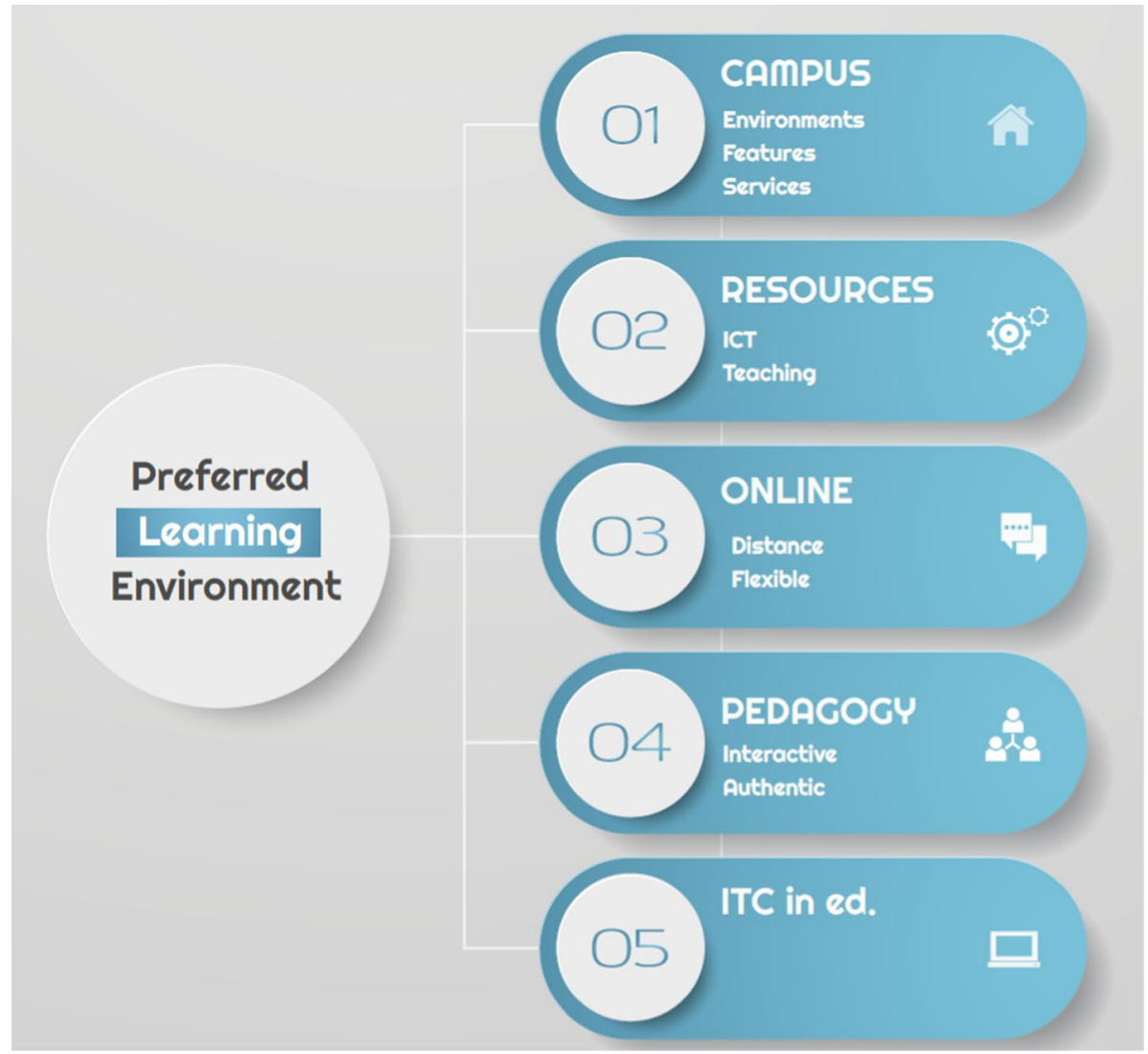

Fig. 1 Categories for preferred learning environments

Also, places for self-study should be developed. There is no room in the library, and if the computers won't work, you have to go home. It would help [a lot] if there were more spaces for studying and learning.

It would be good for learning if there were areas for self-directed learning, quiet areas for studying alone, and areas for working in groups.

There could be more 'corners' for studying.

The second sub-category, features, focused on the learning spaces described above and other physical spaces on campus. Responses were typically short and focused on what the environments should be like. The features most commonly mentioned were comfortable and cozy, referring to places with good air quality and acoustics and that were ergonomic, spacious, warm, and aesthetically pleasing. This category contained several descriptions of what the physical spaces should be like to make them appealing and cozy:

Relaxing study areas, cozy places, quiet spaces, etc.

Buildings need to be in shape. For example, ventilation; temperature affects one's vitality and, from there, one's concentration and learning ability. 
The third sub-category, services, focused on what should be provided by the universities. This category was smaller than the previous two and explored respondents' desires related to a campus area that functioned well. The most-mentioned feature was the hope that campus buildings would be open for students at later hours or even at all hours. Respondents also mentioned the need for parking, gyms, cafeterias, etc. Altogether, the services identified were thought to make studying on campus more comfortable and easier:

[There should be] areas of working in groups with cafeteria services...

Self-study areas that are open 24/7, with computers, printers, chairs, couches, etc.

The second main category was resources which included two sub-categories (ICT and teaching). ICT referred to the availability of functioning technology. For example, these comments referred to the availability of computers with working Internet connection. Respondents assumed that the universities were responsible for providing ICT applications for learning. Comments referring to the BYOD approach were minimal, although respondents expressed a desire for more places where they could charge their personal ICT devices:

Multiple possibilities for using technology-for example, computers in computer labs need to be up to date with scanners, printers, etc.

Limited number of computers in the library makes studying much more challenging.

Responses in this category also indicated the importance of teaching for providing help and instructing students on how to use different technologies for learning. Respondents suggested that it was important to heighten students' interest in studying and motivate them to independently explore the potential of different technologies:

In order for students to be able to take advantage of online environments, there should be instructions and support available at the beginning of their studies.

... [the] possibilities of technologies should be better explained to students in order to help them understand that they can use technologies spontaneously by themselves.

Responses in this sub-category also referred to the need for teachers with up-to-date pedagogical skills, the ability to create effective learning materials, and the capacity to take advantage of ICT when needed. These comments also highlighted the importance of not just having a sufficient number of teachers, but having teachers and professors who are readily available to provide support when needed:

More teaching resources are needed so that we can have the necessary number of high-quality teachers.

It is important that teachers can be reached easily when needed.

The third main category, online, involves the flexibility of studies and the need to consider the unique life situations of different students. Learning online, in one's own way, and at one's own pace were emphasized. The sub-category, distance, involves students' desire for the opportunity to study online as much as possible. Within this sub-category, students suggested online lectures with recordings, online examinations, and opportunities to participate and collaborate online. These responses emphasized the appeal of being able to study without going to campus: 
Students may be in very different situations: someone might have kids or a family, be working, be a distance student, etc. If there were more options for studying (for example, online), this would be easier and more convenient [for us].

[The] possibility for flexible ways to study, even distance teaching, so that when you want to, you can listen to parts of the lectures online in real time and then you would also be able to comment and participate.

The second sub-category, flexible, pertains to having an influence on how studying is accomplished (e.g., assessment types and ways of working during courses) and having the option to study alone. Additionally, responses indicated that students need to be able to manage their own study timetables, including when to study and for how long:

There must be options for studying that better consider the needs of different students (life situations, long distances to university, studying and working at the same time, etc.).

[The] possibilities for multiple ways of accomplishing courses [and having] more choices. More ways to show what one has learned [and] what one knows.

[The] best learning environment... takes students' different needs and hopes into consideration and would accept it if, every now and then, the students won't be able to physically attend [their classes].

The fourth main category, pedagogy, refers to ways of teaching and learning. The first subcategory, interactive, focuses on pedagogy that de-emphasizes lecturing and emphasizes more-interactive teaching and learning strategies. Comments focused on practices aligned with flexible and blended learning. Within this category, there was strong emphasis on face-to-face teaching, interactive teaching methods, and working in small groups. Additionally, support and guidance were suggested, with students taking a more-responsible role in the learning process. Nevertheless, within the responses, there were also mentions of preferring traditional lectures:

Adequately teaching online and in face-to-face situations.

Lectures need to be changed to something wherein students are more active, and the sessions use a more participatory approach.

Different teaching methods should be used with different group sizes, including working in small groups.

In another sub-category in the pedagogy category, authentic, students emphasized a pragmatic approach with more real-life examples. In particular, participants expressed hopes for more internship periods, connections to working life, and collaborations with research groups. Within this sub-category, there was also emphasis on having university researchers provide real examples of their research and work:

There should be more internship periods, especially at the beginning of [our] studies.

... it should be easy for students to be part of research groups' work in the early phases of their studies.

[There should be] more collaborations between university and working life.

The last main category, ICT in education, involves supporting teaching and learning with different technologies. Responses focused mainly on the use of different online 
environments, especially the role of the LMS-like Moodle. The role of cloud services was considered to be smaller. Responses also emphasized the ease of use of different technologies for learning and indicated a preference for using fewer well-justified pedagogical technologies instead of multiple applications and tools simultaneously:

Online environments like Moodle need to be adjusted to be flexible, personalized, and easy to use.

There are a lot of discussions concerning online learning environments. Still, they are not yet used actively and systematically.

Moodle needs to be developed to be more compatible with OneDrive and other cloud services. Currently, using them at the same time is complicated.

\section{Frequency of mentions of categories}

The frequency of mentions of categories and sub-categories is listed in Table 4 which shows that the most- commonly mentioned sub-categories were campus $(\mathrm{f}=139, \mathrm{n}=76$ ) and resources $(\mathrm{f}=122)$. These were followed by online $(\mathrm{f}=100)$, pedagogy $(\mathrm{f}=77)$, and ICT in education $(\mathrm{f}=48)$. These results indicate the high importance of physical spaces as part of students' preferred learning environments. Similarly, useful resources and flexible learning opportunities were considered crucial factors by students. The frequencies in parentheses (f) refer to the total number of mentions, whereas n refers to the number of respondents who mentioned the category. This variable indicates that one respondent could have mentioned one or more categories within his/her responses.

When considering the sub-categories, ICT $(\mathrm{f}=76)$ was the most frequently-mentioned area under resources, indicating the need for ICT resources and support for using them. Features $(\mathrm{f}=62)$ and environments $(\mathrm{f}=60)$ in the campus category were also mentioned often, suggesting the need for comfortable self-study areas. Similarly, interactivity $(f=59)$ in the pedagogy category and distance $(\mathrm{f}=54)$ in the online category were often mentioned, indicating the need to move away from lecturing to more-interactive approaches along with different and more- flexible online learning options. The smallest sub-categories were authenticity $(n=18)$ and services $(n=17)$. The remaining categories were mentioned 46 to 59 times.

\section{Discussion}

Our analysis of the qualitative data aligns well with previous definitions of learning environments by Manninen et al. (2007) and Radcliffe (2008), focusing on physical spaces and pedagogical and technological aspects. Further, the flexibility sub-category can be seen as an important aspect of studying at the university. This category relies on ICT, especially online learning opportunities that can make more-flexible learning opportunities possible. Also, responses focused mainly on informal learning environments instead of formal classrooms or lecture halls. This aligns with Jamieson (2009) who concluded that the focus of education should be broadened beyond formal classrooms and that the whole campus, in fact, should be considered a learning center. Responses provide insight into the learning 


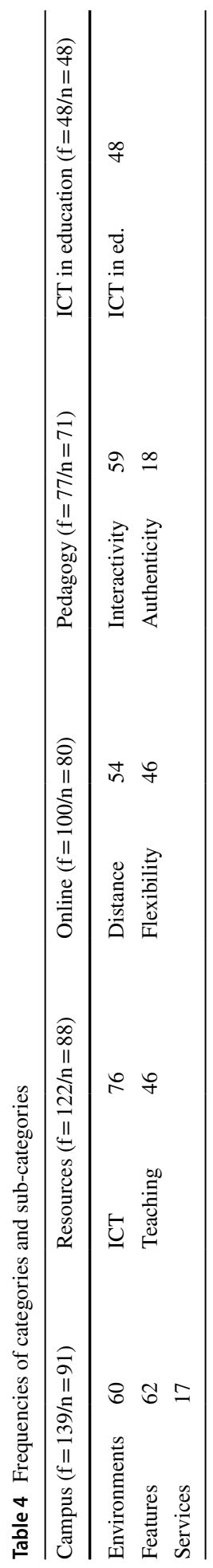


environment as a more-comprehensive entity reflecting different aspects related to studying at university.

The quantitative part of this study indicates rather neutral opinions concerning physical spaces, ICT, and pedagogy. These elements were rated around the mid-point of the scales, with rather small differences. The areas that differed most were the low assessments of the availability of solitary and group working areas and of the use of personal devices. That other areas received moderate ratings indicated that students were rather contented, but still saw room for improvement. In the qualitative data, the need for comfortable learning environments outside the classroom for self-studying or studying in small groups was again emphasized, with participants stressing the importance of having access to informal learning environments. These results align with the findings of Van Note Chism (2002) and Morieson et al. (2018), who highlighted the importance of comfortable areas where students can work alone or with their peers. The current study also indicates the importance of applying interactive pedagogical approaches and ensuring the availability of enough teachers and support staff. Altogether, these provide a picture of students' preference for higher-education learning as a communal process. These results also reflect a change in higher-education pedagogy (Harasim 1996) from mere lecturing to more student-centered approaches to better meet students' learning needs. Contrary to assumptions related to highly self-directed and goal-directed learners (Ossiannilsson 2018), students still expressed a need for greater support (i.e. the presence of teachers and other staff).

This study identified the need for flexible opportunities for studying and participating using online resources (i.e., with minimal time spent on campus), which could be explained by the changing student population. As noted by Ahrio (2012), today's students often have other duties, such as work or family, that make full-time participation in face-to-face teaching challenging or impossible. Although this indicates a demand for more-flexible learning opportunities, it also emphasizes the importance of participating and collaborating with peers using different technologies or modified timetables. In this case, the role of ICT can be seen from two perspectives. Students first indicated the need for ICT devices provided by the university; second, they expressed a need for this technology to be used to support teaching in justified ways. Again, considering previous expectations related to modern students equipped with personal ICT devices (Ossiannilsson 2018), it is surprising that they would still consider having access to computers provided by the university as an important aspect of learning environments.

There is also a need to offer students more-flexible learning opportunities. Some students are unable to come to campus to participate in face-to-face meetings as traditional full-time students. In order to meet these students' needs and provide them with a functional learning environment, flexible participation options (time and place) are required. This requires educators to develop new face-to-face teaching strategies, allow distance participation, or introduce ways to study online (e.g., MOOCs). These results again indicate students' need to participate and the relevant support to help them achieve this. This suggests that, even for students studying online, it is necessary to develop collaborative activities that offer opportunities to work with peers.

A central aspect of the results is students' preference to have different areas for learning, self-studying, and working in groups, as well as other informal areas for learning on campus. In accordance with Van Note Chism (2002) and Harasim (1996), there has been a shift away from knowledge transmission toward more student-centered learning practices. In other words, current practices emphasize knowledge construction rather than knowledge transmission. In practice, this means a different kind of studying. Different methods, such as flipped classroom or PBL, demand learning environments that are suitable for 
collaboration among students who are working on the same topics. These methods also demand spaces and facilities for working on the topics outside classrooms or lecture halls. Students are expected to deal with complex issues, complete assignments, conduct inquiries, collect information, and produce presentations or other artifacts, among other responsibilities. These activities align closely with modern working life and the acquisition of the twenty-first-century skills (Voogt and Pareja Roblin 2012). The results (i.e., need for selfstudying and group working areas) highlight this relation. Furthermore, student-centered activities demand proper spaces with ICT resources and other forms of support, such as the presence of teaching personnel.

\section{Limitations and future directions}

Responses focused mainly on informal learning environments. Comments about classrooms and other environments, which referred to environmental features such as light, air quality, and coziness), were descriptive. Our assumption about the reason behind the general nature of these descriptions is that respondents were not necessarily capable of elaborating on structural and functional elements of learning spaces, such as furniture design or their arrangement. Specifically, students might not possess the pedagogical or content expertise required to consider the characteristics of functional environments for learning. Nevertheless, the results provide an important overview of the development of learning environments in higher education.

Findings from the quantitative and qualitative sections support each other. Responses from the quantitative section show that the availability of self-study areas is perceived as being low. Similar preferences are reflected in the qualitative results. We see this as the most important result and as the main value of this research. Even though Barr and Tagg (1995) and Harasim (1996) identifies changes in higher-education pedagogy over 20 year ago, this topic remains important, especially from the perspectives of learning environments.

The standard deviations within the quantitative results were rather large, indicating strong variation among respondents. We assume that this can be attributed to different backgrounds among respondents from different faculties. Still, our aim was not to study current differences among faculties, but to gain an overview of students' perceptions. The next step will be analyses that emphasize more-diverse student profiles. Future studies must focus more on the needs and hopes of students with different backgrounds and life circumstances in order to provide a more-detailed picture of students' needs related to higher-education learning environments. This information would allow us to reflect, in more detail, on how to support university teachers and universities as a whole in their efforts to improve the quality of university education (Hirsto and Löytönen 2011) and support for student learning. In addition, future research should focus on the co-existence of different categories identified in the current work in an attempt to provide better insights into the best learning environments from the students' perspective.

\section{Conclusion}

This article identified students' perceptions of the preferred learning environments that they consider suitable for today's higher-education needs. The categories identified align with and extend previous definitions of learning environments in the literature. Furthermore, 
students' needs differed based on their perspectives of the learning environments. The emergence of new pedagogical approaches, technologies, and learning needs, as well as changes in students' personal situations, will constantly challenge requirements for learning environments that provide suitable facilities and support for learning. By highlighting students' voice, this article provides ideas and perspectives for policymakers for developing and designing better learning environments for current higher-education needs.

Funding Open access funding provided by University of Eastern Finland (UEF) including Kuopio University Hospital.

Open Access This article is licensed under a Creative Commons Attribution 4.0 International License, which permits use, sharing, adaptation, distribution and reproduction in any medium or format, as long as you give appropriate credit to the original author(s) and the source, provide a link to the Creative Commons licence, and indicate if changes were made. The images or other third party material in this article are included in the article's Creative Commons licence, unless indicated otherwise in a credit line to the material. If material is not included in the article's Creative Commons licence and your intended use is not permitted by statutory regulation or exceeds the permitted use, you will need to obtain permission directly from the copyright holder. To view a copy of this licence, visit http://creativecommons.org/licenses/by/4.0/.

\section{References}

Ahrio, L. (2012). Modernin yliopisto-opiskelun toimintakertomus. Tampere: Tampere University Press.

Alexander, B., Ashford-Rowe, K., Barajas-Murphy, N., Dobbin, G., Knott, J., McCormack, M., et al. (2019). NMC Horizon report: 2018 higher education edition. Louisville, CO: EDUCAUSE.

Al-Samarraie, H., \& Saeed, N. (2018). A systematic review of cloud computing tools for collaborative learning: Opportunities and challenges to the blended-learning environment. Computers \& Education, 124, 77-91.

Barr, R. B., \& Tagg, J. (1995). From teaching to learning-A new paradigm for undergraduate education. Change: The magazine of higher learning, 27(6), 12-26.

Becker, S., Brown, M., Dahlstrom, E., Davis, A., DePaul, K., Diaz, V., et al. (2018). NMC Horizon report: 2018 higher (education ed.). Louisville, CO: EDUCAUSE.

Beckers, R., Van der Voordt, T., \& Dewulf, G. (2015). A conceptual framework to identify spatial implications of new ways of learning in higher education. Facilities, 33(1/2), 2-19.

Beckers, R., Van der Voordt, T., \& Dewulf, G. (2016). Learning space preferences of higher education students. Building and Environment, 104, 243-252.

Carr, N., \& Fraser, K. (2014). Factors that shape pedagogical practices in next generation learning spaces. In K. Fraser (Ed.), The future of learning and teaching in next generation learning spaces (Vol. 12). Bingley, UK: International Perspectives on Higher Education Research, Emerald.

Casanova, D., Di Napoli, R., \& Leijon, M. (2018). Which space? Whose space? An experience in involving students and teachers in space design. Teaching in Higher Education, 23(4), 488-503.

Chatzidiakou, L., Mumovic, D., \& Summerfield, A. J. (2012). What do we know about indoor air quality in school classrooms? A critical review of the literature. Intelligent Buildings International, 4(4), $228-259$.

Cheng, G., Guan, Y., \& Chau, J. (2016). An empirical study towards understanding user acceptance of bring your own device (BYOD) in higher education. Australasian Journal of Educational Technology, 32(4), $1-17$.

Creswell, J. (2003). Research design: Qualitative, quantitative, and mixed methods approach (2nd ed.). Thousand Oaks, CA: Sage Publications.

Fisher, K., \& Newton, C. (2014). Transforming the twenty-first-century campus to enhance the net-generation student learning experience: Using evidence-based design to determine what works and why in virtual/physical teaching spaces. Higher Education Research and Development, 33(5), 903-920.

Gibbs, G. (2007). Analysing qualitative data. London: Sage Publications.

González-Martínez, J. A., Bote-Lorenzo, M. L., Gómez-Sánchez, E., \& Cano-Parra, R. (2015). Cloud computing and education: A state-of-the-art survey. Computers \& Education, 80, 132-151. 
Harasim, L. (1996). Online education. In T. Harrison \& T. Stephe (Eds.), Computer networking and scholarly communication in the twenty-first-century university (pp. 203-214). New York: State University of New York Press.

Harris, M., \& Cullen, R. (2008). Learner-centered leadership: An agenda for action. Innovative Higher Education, 33, 21-28.

Hennessy, S., \& Murphy, P. (1999). The potential for collaborative problem solving in design and technology. International Journal of Technology and Design Education, 9(1), 1-36.

Hirsto, L. (2013). Palautepohjainen opetuksen kehittäminen ja laatu. In J. Hakala \& K. Kiviniemi (Eds.), Vuorovaikutuksen jännitteitä ja oppimisen säröjä. Aikuispedagogiikan haasteiden äärellä (pp. 147-162). Retrieved from https://jyx.jyu.fi/dspace/bitstream/handle/123456789/48383/978-951-395376-8.pdf? sequence $=1$.

Hirsto, L., \& Löytönen, T. (2011). Kehittämisen kolmas tila? -Yliopisto-opetus kehittämisen kohteena [A third space for development? Developing university teaching]. Aikuiskasvatus, 31(4), 255-266.

Hung, W., Jonassen, D. H., \& Liu, R. (2008). Problem-based learning. In J. M. Spector, J. G. Merriënboer, M. D. Merrill, \& M. Driscoll (Eds.), Handbook of research on educational communications and technology (3rd ed., pp. 485-506). Mahwah, NJ: Erlbaum.

Häkkinen, P., Järvelä, S., Mäkitalo-Siegl, K., Ahonen, A., Näykki, P., \& Valtonen, T. (2017). Preparing teacher-students for twenty-first-century learning practices (PREP 21): A framework for enhancing collaborative problem-solving and strategic learning skills. Teachers and Teaching, 23(1), $25-41$.

Jamieson, P. (2009). The serious matter of informal learning: From the development of learning spaces to a broader understanding of the entire campus as a learning space. Planning for Higher Education, 37(2), 18-26.

Jessop, T., Gubby, L., \& Smith, A. (2012). Space frontiers for new pedagogies: A tale of constraints and possibilities. Studies in Higher Education, 37(8), 189-202.

Johnson, L., Becker, S., Estrada, V., \& Freeman, A. (2014). NMC Horizon report: 2014 higher (education ed.). Austin, TX: The New Media Consortium.

Jonassen, D. H., \& Hung, W. (2008). All problems are not equal: Implications for problem-based learning. Interdisciplinary Journal of Problem-Based Learning, 2(2), 6-28.

Kärnä, S., Julin, P., \& Nenonen, S. (2013). User satisfaction on a university campus by students and staff. Intelligent Buildings International, 5(2), 69-82. https://doi.org/10.1080/17508975.2013.778810.

Manninen, J., Burman, A., Koivunen, A., Kuittinen, E., Luukannel, S., Passi, S., et al. (2007). Environments supporting learning: Introduction to learning-environment-thinking. Helsinki: Finnish National Board of Education.

McCune, V., \& Entwistle, N. (2011). Cultivating the disposition to understand in 21 st century university education. Learning and Individual Differences, 21(3), 303-310.

Moore, J. L., Dickson-Deane, C., \& Galyen, K. (2011). e-Learning, online learning, and distance learning environments: Are they the same? The Internet and Higher Education, 14(2), 129-135.

Morieson, L., Murray, G., Wilson, R., Clarke, B., \& Lucas, K. (2018). Belonging in space: Informal learning spaces and student experience. Journal of Learning Spaces, 7(2), 12-22.

Olakanmi, E. E. (2017). The effects of a flipped classroom model of instruction on students' performance and attitudes towards chemistry. Journal of Science Education and Technology, 26(1), 127-137.

Ossiannilsson, E. (2018). Promoting active and meaningful learning for digital learners. In J. Keengwe (Ed.), Handbook of research on mobile technology, constructivism, and meaningful learning (pp. 294-315). Pennsylvania: IGI Global.

Radcliffe, D. (2008). A pedagogy-space-technology (PST) framework for designing and evaluating learning places. In D. Radcliffe, W. Wilson, D. Powell, \& B. Tibbetts (Eds.), Learning spaces in higher education: Positive outcomes by design (Proceeding of the next generation learning spaces 2008 colloquium; pp. 11-16). St Lucia, Queensland: The University of Queensland.

Scannell, L., Hodgson, M., Moreno Villarreal, J. G., \& Gifford, R. (2016). The role of acoustics in the perceived suitability of, and well-being in, informal learning spaces. Environment and Behavior, 48(6), 769-795.

Sointu, E. T., Valtonen, T., Hirsto, L., Kankaanpää, J., Saarelainen, M., Mäkitalo, K., et al. (2019). Teachers as users of ICT from the student perspective in higher education flipped classroom classes. Seminar. net, 15(1), 1-15.

Valtonen, T., Hacklin, S., Dillon, P., Vesisenaho, M., Kukkonen, J., \& Hietanen, A. (2012). Perspectives on personal learning environments held by vocational students. Computers \& Education, 58(2), 732-739.

Van Note Chism, N. (2002). A tale of two classrooms. New Directions for Teaching and Learning, 92, 5-12.

Vercellotti, M. L. (2018). Do interactive learning spaces increase student achievement? A comparison of classroom context. Active Learning in Higher Education, 19(3), 197-210. 
Voogt, J., \& Pareja Roblin, N. (2012). A comparative analysis of international frameworks for 21st century competences: Implications for national curriculum policies. Journal of Curriculum Studies, 44(3), 299-321.

Whiteside, A., Brooks, D. C., \& Walker, J. D. (2010). Making the case for space: Three years of empirical research on learning environments. Educause Quarterly, 33(3), 11.

Yang, Z., Becerik-Gerber, B., \& Mino, L. (2013). A study on student perceptions of higher education classrooms: Impact of classroom attributes on student satisfaction and performance. Building and Environment, 70, 171-188.

Publisher's Note Springer Nature remains neutral with regard to jurisdictional claims in published maps and institutional affiliations. 